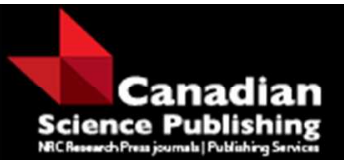

Canadian Journal of Forest Research Revue canadienne de recherche forestière

\title{
Mechanical site preparation and nurse-plant facilitation for the restoration of subarctic forest ecosystems
}

\begin{tabular}{|r|l|}
\hline Journal: & Canadian Journal of Forest Research \\
\hline Manuscript ID & cjfr-2016-0448.R2 \\
\hline Manuscript Type: & Article \\
\hline Date Submitted by the Author: & 17-Mar-2017 \\
\hline Complete List of Authors: & $\begin{array}{l}\text { Thiffault, Nelson; Direction de la recherche forestière } \\
\text { Hébert, François ; Northern Hardwoods Research Institute, }\end{array}$ \\
\hline $\begin{array}{r}\text { Please Select from this Special } \\
\text { Issues list if applicable: }\end{array}$ & N/A \\
\hline \multicolumn{2}{|l}{} \\
\hline
\end{tabular}

SCHOLARONE ${ }^{\mathrm{m}}$

Manuscripts 
1 Mechanical site preparation and nurse-plant facilitation for the restoration of

2 subarctic forest ecosystems

3

4

5 Nelson Thiffault ${ }^{1, *}$ and François Hébert ${ }^{1,2}$

6

$7 \quad{ }^{1}$ Direction de la recherche forestière, Ministère des Forêts, de la Faune et des Parcs du

8 Québec, 2700 Einstein, Québec, QC G1P 3W8, and Centre d'étude de la forêt, Faculté de

9 foresterie, de géographie et de géomatique, Université Laval, 2405 rue de la Terrasse,

10 Québec, QC G1V 0A6

$11{ }^{2}$ Current address: Northern Hardwoods Research Institute, 165 Hébert Blvd.,

12 Edmundston, NB E3V 2S8

13

14 *Corresponding author. Email: nelson.thiffault@mffp.gouv.qc.ca

16 Abstract

17 Sustainable forest management implies successful regeneration following disturbances.

18 Tree regeneration in subarctic ecosystems can however be constrained by limitations to

19 seedling establishment related to cold soils, slow decomposition rates, and competition

20 by ericaceous species. We established a field trial at the northern limit of commercial

21 forests in Québec, Canada, to evaluate how mechanical site preparation (MSP) and

22 planting of a nurse $\mathrm{N}_{2}$-fixing species can promote conifer establishment on a site burned

23 in 2007. The experiment comprised four treatments applied in 2010: standard MSP (disc 
24 trenching); standard MSP + planting of Alnus crispa; intensive MSP, with larger furrows

25 than standard MSP; and a control. Main plots were divided and planted in 2011 with

26 Picea mariana or Pinus banksiana. We monitored seedling survival, growth, nutrition

27 and microsite after three years. Results revealed interactions between treatments and

28 planted species. Mechanical site preparation resulted in higher conifer growth relative to

29 the control conditions, and planting Alnus resulted in growth gains similar as those

30 obtained from intensive MSP. We measured competitive interactions between Alnus and

31 the conifers that might eventually cancel out the initial benefits derived from facilitation

32 by planting the species. Longer-term monitoring of interspecific interactions are needed

33 to further illuminate the mechanisms responsible for the facilitative effect and identify the

34 best management practices.

36 Keywords

37 Reforestation, restoration, boreal forest, conifer, nutrition, competition, regeneration

\section{Résumé}

40 L'aménagement durable des forêts implique que la régénération forestière s'établit avec

41 succès après les perturbations. La régénération forestière dans les écosystèmes

42 subarctiques peut toutefois être problématique en raison des limitations à l'établissement

43 des semis et à la productivité végétale associées aux sols froids, aux faibles taux de

44 décomposition, et à la végétation de compétition dominée par les plantes éricacées. Nous

45 avons installé une expérience à la limite nordique des forêts commerciales du Québec,

46 Canada, pour évaluer comment la préparation mécanique du sol (PM) et la plantation

47 d'une espèce compagne fixatrice d'azote pouvait améliorer l'établissement des conifères 
48 sur un site récemment brûlé. L'expérience comprenait quatre traitements appliqués en

492010 : PM standard (scarifiage à disques); PM standard + plantation d'Alnus crispa; PM

50 intensive avec des sillons plus larges que PM standard; et un témoin. Les parcelles

51 principales ont été divisées et plantées en 2011 avec Picea mariana ou Pinus banksiana.

52 Nous avons mesuré la survie, la croissance, la nutrition et les caractéristiques des

53 microsites des arbres plantés sur une période de trois ans. Les résultats ont révélé des

54 interactions entre la PM et l'espèce plantée. La PM a stimulé la croissance des conifères

55 par rapport au témoin et la plantation d'Alnus a résulté en des gains de croissance

56 similaires à ceux associés à la PM intensive. Nous avons mesuré des interactions

57 compétitives entre Alnus et les conifères, lesquelles pourraient éventuellement annuler les

58 effets bénéfiques initiaux de facilitation s'il advenait qu'elle domine la station. Un suivi à

59 plus long terme de même que l'étude des interactions interspécifiques sont nécessaires

60 afin d'identifier les mécanismes responsables de l'effet de facilitation et identifier les

61 meilleures pratiques d'aménagement.

62

63 Mots-clés

64 Reboisement, restauration, forêt boréale, conifère, nutrition, compétition, régénération 65 


\section{Introduction}

67 Tree density and stocking are critical factors that determine forest productivity (Drew and

68 Flewelling 1979). They both depend directly upon successful tree regeneration following

69 natural and anthropogenic disturbances (Burton et al. 2003; Van Bogaert et al. 2015).

70 Whereas some boreal ecosystems are characterized by an abundant and thriving

71 regeneration layer (e.g., sub-boreal forests of Québec, Canada, which are dominated by

72 balsam fir; Abies balsamea [L.] Miller), tree regeneration in subarctic climates can be

73 constrained by cold air temperatures, short growing seasons, cold soils, slow

74 decomposition rates and, consequently, strong overall limitations to seedling

75 establishment and plant productivity (Saucier et al. 2015). In boreal ecosystems, the

76 failure of natural regeneration after major disturbances can be exacerbated by the absence

77 of advance regeneration (Brumelis and Carleton 1988), insufficient post-disturbance seed

78 rain (Boiffin and Munson 2013), the lack of suitable seedbeds (Dufour-Tremblay et al.

79 2012), or phenol-rich leachates from understory species, particularly ericads such as

80 sheep laurel (Kalmia angustifolia L.) and Labrador tea (Rhododendron groenlandicum

81 (Oeder) Kron \& Judd; Castells et al. 2005; Nilsson and Wardle 2005). Catastrophic

82 wildfire, which is a common disturbance in boreal landscapes, greatly affects the

83 availability of suitable seedbeds for conifer regeneration (Mallik et al. 2010; Nguyen-

84 Xuan et al. 2000). Although severe fires can expose the mineral soil and promote conifer

85 regeneration when seed sources are available, the residual thick and charred organic

86 material that remains after low-intensity fires is a poor germination substrate (Greene et

87 al. 2007). Lack of abundant and well-dispersed natural regeneration a few years

88 following disturbance can lead to net losses of forest productivity and other ecosystem 
89 services, such as carbon sequestration (Kurz et al. 2013). In such cases, rehabilitation

90 efforts are needed to restore desired structure, species compositions, and ecosystem

91 processes (Stanturf and Madsen 2002; Stanturf et al. 2014; Nunez-Mir et al. 2015).

92

93 Restoration planting can be used to accelerate the reconstruction of forest ecosystems on

94 sites where succession would be otherwise delayed for many decades or susceptible to

95 the creation of alternative stable states (Beisner et al. 2003; Hébert et al. 2014). Planted

96 seedlings are exposed to various environmental stresses, which affect their survival and

97 growth (Burdett 1990; Margolis and Brand 1990; Grossnickle 2012). In northern

98 ecosystems, mechanical site preparation offers the potential for improved seedling

99 establishment by reducing competing vegetation cover, increasing soil temperature,

100 mitigating air temperature extremes, and stimulating organic matter decomposition

101 (Prévost 1992; Löf et al. 2012). Successful seedling establishment is often reported as

102 being dependent upon the intensity of mechanical site preparation (e.g., Thiffault et al.

103 2004). For example, the use of double-pass treatments (Thiffault et al. 2005) or

104 increasing disc angle to create larger furrows (Buitrago et al. 2015) is expected to

105 increase planted seedling growth, given that the treatments create larger areas free of the

106 direct and indirect interferences of competing species, especially ericaceous species. Site

107 preparation intensity, however, interacts with site characteristics; more severe treatments

108 are not always followed by increased seedling growth (e.g., Fleming et al. 2014). Also,

109 responses to mechanical site preparation are routinely species-specific. For example, we

110 observed that $15^{\text {th }}$-year leader growth of black spruce (Picea mariana [Miller] BSP) 
111 increased with scarification on a boreal site in Newfoundland (Canada), whereas jack

112 pine (Pinus banksiana Lambert) did not benefit from the treatment (Thiffault et al. 2010).

113

114 Competing vegetation generally hinders the growth and survival of planted conifers.

115 Indeed, studies worldwide have demonstrated that in most cases, the control of competing

116 vegetation results in increased growth of planted seedlings (Walstad and Kuch 1987;

117 Wagner et al. 2005; McCarthy et al. 2011). Yet surrounding vegetation can improve soil

118 moisture, nutrient availability and structure, as well as regulate microclimatic variation

119 (Brooker et al. 2008). These vegetation effects on seedling microclimate can sometimes

120 favour increased nutrient status, which is a positive influence on early seedling growth

121 (Buitrago et al. 2015). In particular, the colonization of bare soils by $\mathrm{N}_{2}$-fixing species

122 potentially ameliorates the growing substrate for later successional species (Walker et al.

123 2003). For example, species within the genus Alnus can fix and utilize atmospheric $\mathrm{N}_{2}$ for

124 growth (Bond 1956), thereby facilitating successional processes (Chapin et al. 1994;

125 Callaway and Walker 1997; Bellingham et al. 2001). Over the long-term, facilitation can

126 increase productivity in planted, mixed-species forests (Piotto 2008; Benomar et al. 2013;

127 Mason and Connolly 2014). Yet gains in productivity are not always measured and they

128 may be highly dependent upon the species that are used (e.g., Nguyen et al. 2012). Thus,

129 there is a trade-off that needs to be addressed between competition and facilitation

130 (Simard et al. 2006). Although companion species can offer protection from harsh

131 conditions (e.g., desiccation, sunscald, or soil $\mathrm{N}$ depletion) and promote conifer survival,

132 they can significantly reduce planted species growth through competition for light, water

133 or nutrients (e.g., Nelson et al. 2012). 
135 Our general objective was to assess the potential for mechanical site preparation and

136 planting of a companion $\mathrm{N}_{2}$-fixing species, mountain alder (Alnus viridis (Chaix) DC ssp.

137 crispa (Aiton) Turrill (Syn = A. crispa [Aiton] Pursh)), to promote planted black spruce

138 and jack pine seedling establishment on a subarctic forest site in northern Québec lacking

139 natural regeneration. We studied black spruce and jack pine because both species

140 naturally regenerate in the study region and constitute the dominant canopy species in

141 these ecosystems. Three growing seasons after planting, we aimed: $i$ ) to evaluate the

142 effects of mechanical site preparation and its intensity, planting of mountain alder, and

143 planted species on ericaceous species cover in planting microsites; $i$ ) to assess the effects

144 of mechanical site preparation intensity, planting of mountain alder as a companion

145 species, and planted conifer species on seedling survival, third year dimensions, leader

146 growth, foliar nutrition, and microsite nutrient availability; and iii) to evaluate whether

147 the effects of alder on black spruce and jack pine are species and distance-dependent.

149 To achieve these objectives, we established a field experiment to test the following

150 hypotheses. First, we predicted that mechanical site preparation results in a lower

151 ericaceous shrub cover than a control treatment (prediction P1), the effect being more

152 important in intensively prepared plots than in plots submitted to a standard treatment

153 (prediction P2). We postulated that planting mountain alder in mechanically prepared

154 plots results in a lower ericaceous cover than following standard mechanical site

155 preparation alone (prediction P3), and that this effect is similar to that of performing an

156 intensive treatment (prediction P4). We did not expect the planted conifer species to 
157 influence the ericaceous shrub cover (prediction P5). We posited that mechanical site

158 preparation positively influences foliar nutrition of the planted conifers, as well as soil

159 nutrient concentrations in their rooting zone (prediction P6). We expected that planting

160 mountain alder results in similar foliar nutrient and soil nutrient concentrations as

161 performing an intensive mechanical site preparation treatment (prediction P7). The

162 magnitude of the treatment effects on foliar and soil characteristics is expected to vary

163 between the planted conifer species (significant interactions) (prediction P8). We

164 hypothesized that seedling survival, dimensions and leader growth are positively related

165 to mechanical site preparation intensity (prediction P9), and that planting mountain alder

166 after standard mechanical site preparation results in similar seedling survival, dimensions

167 and leader growth as performing an intensive site preparation treatment (P10). The

168 planted conifer species is expected to interact with treatments to influence seedling

169 survival, dimensions and growth (significant interactions); we predicted that jack pine is

170 more responsive than black spruce (prediction P11). Finally, we hypothesized that the

171 magnitude of the conifer seedling responses is a function of mountain alder competition

172 expressed as a function of distance and relative height, conifer species, and the

173 interaction between the two (prediction P12).

174

175 Materials and methods

176 Study area and site description

177 We established an experimental plantation in northern Québec, Canada $\left(51^{\circ} 50^{\prime} 40.7^{\prime \prime} \mathrm{N}\right.$,

$\left.17868^{\circ} 15^{\prime} 46.9^{\prime \prime} \mathrm{W}\right)$. The site is about $290 \mathrm{~km}$ north of Baie-Comeau, within the black spruce-

179 feather moss bioclimatic domain, which has been described by Saucier et al. (2009). The 
180 plantation is located at the actual northern limit of commercial forestry in Québec, a limit

181 that is based upon a broad set of criteria (physical environment, timber production

182 capacity, forest vulnerability to fire, and conservation of biodiversity; Jobidon et al.

183 2015). Climate is continental sub-polar sub-humid, with a short growing season (120

184 days). Mean annual temperature is $-2.5^{\circ} \mathrm{C}$ and annual precipitation is $900-1000 \mathrm{~mm}$, of

185 which $40-45 \%$ falls as snow, forming a snow cover of 400-450 cm deep. The study site

186 is about 32 ha in area and characterized as glacial till with a loamy-sand texture (71\%

187 sand, $19 \%$ silt, and $10 \%$ clay in the upper-B horizon). The soil that has developed from

188 this parent material is a Podzol (Soil Classification Working Group 1998) with occasional

189 induration. The mineral soil is covered by a $12-15 \mathrm{~cm}$-thick mor humus. The previous

190 stand, which was 61- to 80-years-old and composed of 12-17 m-tall black spruce with a

191 canopy cover of $41-60 \%$, had been burned by a wildfire in 2007 . The area was not

192 subjected to salvage logging. We conducted visual observations in July 2010 that

193 indicated the abundance of charred organic material and reindeer lichen (Cladina), a lack

194 of natural conifer regeneration, and gradual site encroachment by ericads (mainly

195 Labrador tea).

197 Experimental design and treatments

198 We delimited five blocks varying from 4.6 ha to 7.1 ha (mean of 5.5 ha; standard

199 deviation of 0.9 ha), which we further divided into four main plots of 1.1 ha each

200 separated by 10-15 m buffers. Blocks were irregular in shape and size and delimited to

201 reduce soil variability within each replicate. Within each block, the main plots were

202 randomly assigned to receive one of the following treatments (Fig. 1): 
203 i) standard mechanical site preparation was applied in August 2010 with a T26.a disc

204 trencher (Bracke Forest AB, Bräcke, Sweden) $\left(\mathrm{MSP}_{\mathrm{S}}\right)$;

205 ii) similar to $\mathrm{MSP}_{\mathrm{S}}$ treatment, but followed by systematic planting in June 2011 of

206 alder seedlings that were produced in $110 \mathrm{~cm}^{3}$ containers from local seed sources,

207 at an approximate density of 2000 seedlings $\cdot \mathrm{ha}^{-1}\left(\mathrm{MSP}_{\mathrm{S}}+\mathrm{AC}\right)$;

208 iii) intensive mechanical site preparation that was applied in August 2010 with a T26.a

209 disc trencher, involving a first pass (as in the $\mathrm{MSP}_{\mathrm{S}}$ treatment), followed by a

210 second pass within the same furrows but with an amplified disc angle (relative to

211 the trencher), to create larger furrows $\left(\mathrm{MSP}_{\mathrm{L}}\right)$; and

212 iv) a control treatment (without mechanical site preparation; C).

213 Furrows in the $\mathrm{MSP}_{\mathrm{S}}$ and $\mathrm{MSP}_{\mathrm{S}}+\mathrm{AC}$ treatments (measured in July 2011) were $60 \mathrm{~cm}$

214 wide $($ standard deviation $=16 \mathrm{~cm})$. Furrows in the $\mathrm{MSP}_{\mathrm{L}}$ treatment were $64 \mathrm{~cm}$ wide

215 (standard deviation $=18 \mathrm{~cm}$ ). Although the increase in width was small, the $\mathrm{MSP}_{\mathrm{L}}$

216 treatment was effective in creating significantly larger furrows than the $\mathrm{MSP}_{\mathrm{S}}$ and

$217 \mathrm{MSP}_{\mathrm{S}}+\mathrm{AC}$ treatments $\left(F_{1,3.68}=16.43, P=0.018\right)$. Furrow depth was similar in all

218 treatments involving MSP $\left(\right.$ mean $=31 \mathrm{~cm}$; standard deviation $=10 \mathrm{~cm} ; F_{1,1307}=3.80, P=$ $2190.052)$.

220

221 We divided each main plot into two subplots, which were assigned to be planted

222 randomly either with black spruce or with jack pine seedlings. The resulting experimental

223 design (Fig. 1) was a complete block split-plot assignment with five blocks, four main

224 plots per block, and two subplots per main plot, for a total of 40 experimental units. 
226

227 Conifer seedlings were produced in $110 \mathrm{~cm}^{3}$ containers from local seed sources. Initial

228 stock type dimensions at the time of planting (mean \pm standard deviation) were estimated

229 from a sub-sample of 60 seedlings of each species randomly collected on site. Seedling

230 height $(\mathrm{cm})$ and root-collar diameter $(\mathrm{mm})$ were respectively $32.4 \pm 4.1 \mathrm{~cm}$ and $3.8 \pm 0.6$

$231 \mathrm{~mm}$ for black spruce, and $29.9 \pm 3.6 \mathrm{~cm}$ and $3.4 \pm 0.4 \mathrm{~mm}$ for jack pine.

232

233 Foliar samples were collected from the same seedlings, oven-dried at $65{ }^{\circ} \mathrm{C}$ for $48 \mathrm{~h}$, and

234 ground to pass a 40-mesh screen (particles size $<420$ micron). Ground samples were

235 digested in boiling $\mathrm{H}_{2} \mathrm{SO}_{4}$ and $\mathrm{H}_{2} \mathrm{O}_{2}$ (Parkinson and Allen 1975). Nutrient concentrations

236 were determined by flow-injection colorimetry (Quickchem, Lachat, Milwaukee, WI) and

237 inductively coupled plasma spectroscopy (ICAP-9000, Thermo Instruments, Franklin,

238 MA). Initial foliar concentrations did not reveal any major nutrient deficiencies. For

239 black spruce, mean ( \pm standard deviation) concentrations of $\mathrm{N}, \mathrm{P}$ and $\mathrm{K}$ were $20 \pm 23$

$240 \mathrm{mg} \cdot \mathrm{g}^{-1}, 1.9 \pm 0.2 \mathrm{mg} \cdot \mathrm{g}^{-1}$, and $5.3 \pm 0.6 \mathrm{mg} \cdot \mathrm{g}^{-1}$, respectively. Nitrogen, phosphorus and

241 potassium estimates in jack pine were $15 \pm 12 \mathrm{mg} \cdot \mathrm{g}^{-1}, 1.5 \pm 0.2 \mathrm{mg} \cdot \mathrm{g}^{-1}$, and $5.8 \pm 0.7$

$242 \mathrm{mg} \cdot \mathrm{g}^{-1}$, respectively.

243

244 Planted period and method

245 Seedlings were planted on 11-15 July 2011 using a container seedling dibble at $2.0 \times 2.5$

$246 \mathrm{~m}$ spacing, resulting in a planting density of 2000 conifers $\cdot \mathrm{ha}^{-1}$. In scarified plots $\left(\mathrm{MSP}_{\mathrm{S}}\right.$,

$247 \mathrm{MSP}_{\mathrm{S}}+\mathrm{AC}, \mathrm{MSP}_{\mathrm{L}}$ ), seedlings were planted in the hinge position (trench-berm interface). 
248 In $\mathrm{MSP}_{\mathrm{S}}+\mathrm{AC}$ plots, we planted the conifer seedlings independently of the alder seedlings,

249 thereby resulting in various conifer-alder distances over the plots.

250

251 Seedling measurements and microsite characteristics

252 In the approximate centre of each subplot, we established a circular sampling plot of 200

$253 \mathrm{~m}^{2}$ (8 $\mathrm{m}$ radius) in which we tagged all planted conifer seedlings for long-term growth

254 assessments (Fig. 1). Each circular sampling plot contained $45 \pm 1$ planted conifers (mean

$255 \pm$ standard deviation). In each sampling plot, the three seedlings that were closest to the

256 centre were used for further soil and foliage sampling in October 2013. For each of these,

257 we collected a sample of current-year shoots and soil within a $10 \mathrm{~cm}$ radius from the root

258 plug. Foliar samples were used to determine nutrient concentrations (as described above).

259 Soil samples were dried at ambient temperature and ground to pass a $2 \mathrm{~mm}$-mesh screen.

260 Total $\mathrm{N}$ and total $\mathrm{C}$ were determined by high temperature dry combustion $\left(1350{ }^{\circ} \mathrm{C}\right)$,

261 followed by infrared detection of total $\mathrm{C}$ and thermal conductivity detection of total $\mathrm{N}$

262 (TruMac CN Elemental Analyzer, LECO Corporation, St. Joseph, MI, USA). Extractable

$263 \mathrm{P}, \mathrm{K}, \mathrm{Ca}$, and $\mathrm{Mg}$ were extracted in Mehlich-III solution and measured by inductively

264 coupled argon plasma-optical emission spectrometry (Optima 4300 DV, Perkin-Elmer,

265 Norwalk, CT, USA). We determined soil $\mathrm{pH}$ in a $10 \mathrm{~g}$ slurry with deionized water (Fisher

266 Scientific accumet 50, Denver Instrument, Bohemia, NY, USA).

267

268 Tagged seedlings were measured for height $(\mathrm{cm})$ and ground-level diameter $(\mathrm{gld} ; \mathrm{mm})$ in

269 October of the first (2011) and third (2013) growing seasons after planting. In 2011 and

2702013 , we measured the distance between the tagged seedlings and the nearest planted or 
271 naturally established alder seedling in $\mathrm{MSP}_{\mathrm{S}}+\mathrm{AC}$ plots. In 2013, we measured the height

272 of the nearest alder seedling, and also visually estimated the percent cover of ericaceous

273 species within a $50 \mathrm{~cm}$ radius of the planted seedlings (done in the field, using $5 \%$

274 classes; mean of two observers' estimates) (Vanha-Majamaa et al. 2000).

275

\section{$276 \quad$ Statistical analyses}

277 We analyzed the 2013 percent cover of ericaceous shrubs (predictions P1 to P5), foliar

278 and soil nutrient concentrations (predictions P6 to P8), and seedling mensurational data

279 (height, gld, leader growth, the volume index based on the volume of a cone; Wagner and

280 Robinson 2006) (prediction P9 to P11) using mixed-effects analyses of variance

281 (ANOVA), with respect to the experimental design (Littell et al. 2006). Treatments at the

282 whole-plot level $\left(\mathrm{C}, \mathrm{MSP}_{\mathrm{S}}, \mathrm{MSP}_{\mathrm{S}}+\mathrm{AC}, \mathrm{MSP}_{\mathrm{L}}\right)$, at the subplot-level (black spruce, jack

283 pine), and their interactions were considered as fixed effects, while blocks and

284 interactions with blocks were considered as random effects. Survival data were not

285 subjected to statistical analyses, as seedling mortality was marginal (see Results). All data

286 were verified for normality and homoscedasticity assumptions using the Shapiro-Wilk

287 statistics and standard graphical approaches (plots of residuals against fitted values and

288 probability plots). Natural-log, square-root, or inverse sine transformations were applied

289 when necessary (see table footnotes). In such cases, for the sake of clarity we present

290 back-transformed means and confidence intervals after bias correction (Ung and Végiard

291 1988; Végiard and Ung 1993). All ANOVAs were conducted with the MIXED procedure

292 of SAS (v. 9.3, SAS Institute, Cary, NC, USA). Denominator degrees of freedom for the

$293 \quad F$-tests were computed using the Kenward-Roger approximation (Schaalje et al. 2001). In 
294 case of significant $F$ of the ANOVAs, treatments were compared using least square mean

295 tests. Inferential statistics were based on $\alpha=0.05$ as the significance threshold.

296

297 To test prediction P12, we used data from only the $\mathrm{MSP}_{\mathrm{S}}+\mathrm{AC}$ plots and investigated how

298 distance between planted conifers and the nearest alder seedling influenced tree diameter.

299 To do so, the distance and relative height of alder in relation to the target conifers were

300 used to calculate angular height (Fig. 2), a distance-dependent competition index (Biging

301 and Dobbertin 1992). Angular height, in turn, was considered, together with species and

302 their interaction, in a linear regression as a predictor of tree diameter using the MIXED

303 procedure of SAS, with Block and Block $\times$ Species as random effects. We used diameter

304 as a response variable because of its known sensitivity to competition for light compared

305 to height (e.g., Wagner and Robinson 2006). Given that the Angular height $\times$ Species

306 interaction was not significant $\left(F_{1,305}=2.88, P=0.091\right)$, we re-ran the model without the

307 interaction term, thereby accounting for a common slope but distinct intercepts between

308 species. We took into account the heterogeneous variance among species using the

309 GROUP option of the REPEATED statement in the MIXED procedure of SAS (Littell et

310 al. 2006). We then calculated the likelihood-ratio-based $R^{2}\left(R^{2}{ }_{\mathrm{LR}}\right)$ for the relationship

311 (Magee 1990).

312

\section{Results}

314 Percent cover of ericaceous shrubs (predictions P1 to P5)

315 There was a significant effect of mechanical site preparation on percent cover of

316 ericaceous species after three growing seasons $\left(F_{3,32.3}=32.91, P<0.001\right)$; percent cover 
317 was significantly higher $\left(t_{32.3} \geq 7.97, P<0.001\right)$ in the controls $(33 \%)$ compared to the

318 other treatments including the Alnus planted plots $(8 \%)$. The $\mathrm{MSP}_{\mathrm{S}}, \mathrm{MSP}_{\mathrm{S}}+\mathrm{AC}$ and

$319 \mathrm{MSP}_{\mathrm{L}}$ treatments did not differ from one another $\left(t_{32.6} \leq 0.24, P \geq 0.816\right)$. The planted

320 species did not significantly influence the percent cover of ericaceous shrubs $\left(F_{1,32.3}=\right.$

$3210.94, P=0.340$; data not shown).

322

323 Foliar nutrient concentrations and soil characteristics (predictions P6 to P8)

324 Treatment effects on seedling foliar nutrient concentrations were similar across species

325 (no significant interaction; Table 1). All treatments increased foliar $\mathrm{N}\left(16 \mathrm{mg} \mathrm{g}^{-1}\right)$ and P

$326\left(1.9 \mathrm{mg} \mathrm{g}^{-1}\right)$ concentrations relative to the controls $\left(\mathrm{N}=11 \mathrm{mg} \mathrm{g}^{-1} ; \mathrm{P}=1.7 \mathrm{mg} \mathrm{g}^{-1} ; t_{31.8} \geq\right.$

$327|-2.18|, P<0.001)$, but did not differ from one another $\left(t_{32.3} \leq 1.82, P \geq 0.077\right)$. Foliar $\mathrm{K}$,

$328 \mathrm{Ca}$ and $\mathrm{Mg}$ were not influenced by the treatments (Table 1). Regardless of the treatments,

329 the species effect was highly significant for foliar N, P, K and Ca (Table 1), but its

330 direction varied depending upon nutrient. We measured higher foliar $\mathrm{P}, \mathrm{K}$ and $\mathrm{Ca}$

331 concentrations in black spruce $\left(\mathrm{P}=2.05 \mathrm{mg} \mathrm{g}^{-1} ; \mathrm{K}=6.7 \mathrm{mg} \mathrm{g}^{-1} ; \mathrm{Ca}=3.02 \mathrm{mg} \mathrm{g}^{-1}\right)$ than in

332 jack pine $\left(\mathrm{P}=1.65 \mathrm{mg} \mathrm{g}^{-1} ; \mathrm{K}=5.2 \mathrm{mg} \mathrm{g}^{-1} ; \mathrm{Ca}=1.97 \mathrm{mg} \mathrm{g}^{-1}\right)$, but foliar $\mathrm{N}$ was higher in

333 jack pine $\left(16 \mathrm{mg} \mathrm{g}^{-1}\right)$ than in black spruce $\left(13 \mathrm{mg} \mathrm{g}^{-1}\right)$. Foliar magnesium concentrations

334 were similar across species (Table 1).

335

336 Species and the treatments interacted to influence concentrations of soil nutrients, $\mathrm{pH}$ and

337 cation exchange capacity (Table 1). Detailed analysis of the interaction showed that for

338 both species, soil $\mathrm{N}$ and $\mathrm{P}$ concentrations were similar in control, $\mathrm{MSP}_{\mathrm{S}}, \mathrm{MSP}_{\mathrm{S}}+\mathrm{AC}$ and

$339 \mathrm{MSP}_{\mathrm{L}}$ plots $(P \geq 0.088)$, but species had significant effects on these variables in some 
340 treatments. For example, soil $\mathrm{N}$ was similar under jack pine seedlings and black spruce

341 seedlings in control plots, but higher under jack pine than black spruce in $\mathrm{MSP}_{\mathrm{S}}$ and

$342 \mathrm{MSP}_{\mathrm{S}}+\mathrm{AC}$ plots. The species effect was reversed in $\mathrm{MSP}_{\mathrm{L}}$ plots. Soil $\mathrm{P}$ concentrations

343 were higher under black spruce than jack pine in $\operatorname{MSP}_{\mathrm{S}}$ plots $\left(F_{1,95}=69.07, P<0.001\right)$,

344 but similar among species in the other treatments $\left(F_{1,95} \leq 1.05, P \geq 0.308\right)$. Soil $\mathrm{K}$ was

345 lower in all treated plots compared to control plots, but only when black spruce was

346 planted $\left(F_{3,21.4}=5.26, P=0.007\right)$. We measured no such effect in jack pine-planted plots

$347\left(F_{3,21.2} \leq 2.66, P=0.074\right)$. Soil $\mathrm{K}$ concentrations were higher under jack pine than black

348 spruce in the $\mathrm{MSP}_{\mathrm{S}}$ and $\mathrm{MSP}_{\mathrm{S}}+\mathrm{AC}$ plots $\left(F_{1,95} \geq 12.07, P<0.001\right)$. Soil pH was similar

349 across treatments in the jack pine-planted plots $\left(F_{3,14.3}=0.72, P=0.554\right)$, but not in black

350 spruce-planted plots $\left(F_{3,14.4}=4.21, P=0.025\right)$. We measured no treatment effect on CEC

$351\left(F_{3,17.6} \leq 0.77, P=0.525\right)$, but species affected this variable in the $\mathrm{MSP}_{\mathrm{S}}$ and $\mathrm{MSP}_{\mathrm{S}}+\mathrm{AC}$

352 plots $\left(F_{1,95} \geq 6.65, P \leq 0.012\right)$.

353

354 Seedling survival, dimensions and leader growth (predictions P9 to P11)

355 Seedling survival was $>99 \%$ for both species after three growing seasons, preventing

356 any statistical analysis (the occurrence of dead seedlings was too low for models to

357 converge). The treatments and species had significant effects on seedling third-year

358 height, diameter, volume and leader growth, either alone or in combination (Table 2).

359 While standard mechanical site preparation $\left(\mathrm{MSP}_{\mathrm{S}}\right)$ did not result in significantly higher

360 third-year height compared to control conditions, both the planting of an $\mathrm{N}_{2}$-fixing

361 companion species $\left(\mathrm{MSP}_{\mathrm{S}}+\mathrm{AC}\right)$ and the creation of larger furrows $\left(\mathrm{MSP}_{\mathrm{L}}\right)$ resulted in

362 taller seedlings than the control and $\mathrm{MSP}_{\mathrm{S}}$ treatments three years after planting, 
363 regardless of the species (Fig. 3a). After three growing seasons, jack pine seedlings were

364 taller than black spruce seedlings (Fig. 3b). Treatments had a significant, positive effect

365 on seedling third-year diameter, but the effect was not the same for black spruce and jack

366 pine. Large furrows $\left(\mathrm{MSP}_{\mathrm{L}}\right)$ further increased black spruce diameter compared to $\mathrm{MSP}_{\mathrm{S}}$

367 and $\mathrm{MSP}_{\mathrm{S}}+\mathrm{AC}$, but did not differ from $\mathrm{MSP}_{\mathrm{S}}+\mathrm{AC}$ for jack pine diameter (Fig. 3c).

368 Leader growth also responded to a significant Treatment $\times$ Species interaction: black

369 spruce was sensitive to an increase in treatment intensity, whereas jack pine only

370 responded to the presence or absence of mechanical site preparation (Fig. 3d). Seedling

371 volume index positively responded to mechanical site preparation intensity and jack pine

372 seedlings attained a volume index three times greater than that of black spruce seedlings

373 (data not shown).

375 Competitive effect of the nearest alder (prediction P12)

376 Alder seedlings were taller, in average, than both black spruce and jack pine seedlings

377 (Fig. 3b). Angular height between alder seedlings and planted conifers (measured in

378 October 2013) was a significant predictor of seedling ground-level diameter $\left(F_{1,329}=\right.$

$3798.79, P=0.003$; Fig. 4). Conifer seedling diameter significantly decreased as angular

380 height increased. The linear model explained two thirds of the variation in the response

381 variable (Fig. 4).

382

383 Discussion

384 Effects of mechanical site preparation and its intensity 
385 Conifer seedling growth responded positively to mechanical site preparation when

386 compared to direct planting without humus management. This response to scarification is

387 typical for newly planted conifers on boreal sites (e.g., Johansson et al. 2013). However,

388 this study is one of the few (Hébert et al. 2014) that has tested the treatment at the

389 northern limit of commercial forestry in Québec, demonstrating the potential for

390 silviculture to restore forest cover in this sensitive zone (sensu Van Bogaert et al. 2015).

391 The positive effect of mechanical site preparation on seedling growth was related to

392 improved microsite conditions (Löf et al. 2012), such as an increase in soil temperature

393 (Thiffault and Jobidon 2006; Wallertz and Malmqvist 2013), a decrease in competing

394 vegetation cover (e.g., Nilsson and Örlander 1999), and positive effects of soil mixing on

395 organic matter decomposition (Salonius 1983; Pelletier Bergeron et al. 2013). Indeed,

396 mechanical site preparation reduced ericaceous species cover four-fold around the

397 planted seedlings, which resulted in increased foliar $\mathrm{N}$ and $\mathrm{P}$, thereby promoting seedling

398 growth (Yamasaki et al. 2002).

399

400 In Europe and parts of Asia, mechanical site preparation is effective in reducing planted

401 seedling mortality that is due to insect attacks, particularly weevils (Björklund et al.

402 2003; Löf et al. 2012; Wallertz and Malmqvist 2013). The exposed bare soil creates a

403 protective barrier minimizing damage that is incurred by insect pests (Petersson et al.

404 2005). In the present study, seedling survival was not affected by mechanical site

405 preparation. In fact, less than $1 \%$ of the seedlings had died after three growing seasons

406 and, thus, all treatments were confounded. We attribute the high survival rate to the

407 scarcity of defoliating insects or bark beetles in this region (Beaudoin et al. 2014). Also, 
408 the high precipitation regime and thick snow cover likely reduced risks of water stress

409 during summer (Grossnickle 2012) and desiccation during winter (Frey 1983).

410

411 Increasing the intensity of silviculture generally results in accelerated growth of planted

412 conifers (Park and Wilson 2007). In this harsh subarctic ecosystem, black spruce and jack

413 pine seedlings positively responded to the creation of slightly larger furrows in the $\mathrm{MSP}_{\mathrm{L}}$

414 plots, compared to those found in the $\mathrm{MSP}_{\mathrm{S}}$ plots. By exposing the mineral soil,

415 mechanical site preparation causes soil warming because of increased solar radiation and

416 thermal diffusivity (Sutherland and Foreman 1995). Removing the humus layer (which

417 acts as a thermal insulator) over a larger surface in the $\mathrm{MSP}_{\mathrm{L}}$ plots compared to the $\mathrm{MSP}_{\mathrm{S}}$

418 plots might have enabled higher soil temperatures in this treatment (Spittlehouse and

419 Stathers 1990). We did not measure this variable, but it might have had positive impacts

420 on seedling growth (Thiffault and Jobidon 2006).

421

422 Facilitative and competitive effects of alder

423 The facilitative nature of alder species has been observed in various contexts (e.g.,

424 Binkley et al. 1992). For example, mountain alder naturally colonizes boreal sites after

425 major perturbations (Matthews 1992); it then modifies site conditions in ways that favour

426 the survival and growth of Engelmann spruce (Picea engelmannii Parry ex Engelm.), for

427 example, and other late-successional species (Blundon and Dale 1990). Yet natural alder

428 regeneration might not establish rapidly enough (or not at all) to play a significant role as

429 a nurse species for desirable conifers in a restoration context (Castro et al. 2002). 
431 We evaluated whether planting alder as a $\mathrm{N}_{2}$-fixing nurse-species after conventional disc-

432 trenching would lead to accelerated growth of conifers planted on a site that was subject

433 to harsh subarctic conditions, compared to direct planting or scarification only. Planting

434 alder in scarified plots resulted in third-year conifer height responses similar to those

435 using intensive mechanical site preparation (large furrows). We measured the same type

436 of response for jack pine seedling diameter, demonstrating a facilitation effect of the $\mathrm{N}_{2}$ -

437 fixing species on conifer regeneration in a harsh subarctic ecosystem.

439 Our study did not allow us to identify the specific mechanism responsible for this positive

440 effect of alder on conifer dimensions. We expected that alder would benefit conifer

441 growth principally by increasing soil available-N through litter decay, but we did not

442 detect this effect when measuring mineral-N concentrations in the vicinity of the seedling

443 root plug. However, conifers are known to produce adventitious roots in the organic layer

444 (Krause and Morin 2005), a horizon in which seedlings might have benefited from the

445 mineralization of N-rich alder litter (Titus 2008). We also posited that increasing alder

446 cover through planting would deter ericaceous shrub encroachment on conifer microsites,

447 thereby reducing competition by problematic species such as Labrador tea or sheep

448 laurel. After three growing seasons, we did not measure a significant effect of alder on

449 ericaceous shrub cover around the planted conifers, possibly because the nearest alder

450 seedlings were still more than $50 \mathrm{~cm}$ away from the conifers (on average). This suggests

451 the facilitation effect that alder exerted on spruce and pine was related to other

452 mechanisms, such as seedling protection from harsh environmental conditions (Callaway

453 and Walker 1997; Castro et al. 2002). This response is consistent with conclusions that 
454 were reached by Van Bogaert et al. (2015), who identified climatic factors as the

455 principal constraint on conifer regeneration growth at the northern limit of commercial

456 forestry in Québec.

457

458 The presence of alder had an overall positive effect on black spruce and jack pine, but our

459 results demonstrate that competitive interactions occurred between the nurse-species and

460 the planted conifers. We indeed measured a negative relationship between angular height

461 and seedling diameter, indicating that both conifer species were sensitive to overtopping

462 by alder. Cortini and Comeau (2008) similarly reported significant competition by red

463 alder (Alnus rubra Bongard) at the expense of planted western redcedar (Thuja plicata

464 Donn ex D.Don) in British Columbia. We anticipated this negative effect of light

465 competition by mountain alder on seedling growth. Because of their inherent differences

466 in terms of both shade tolerance (Burns and Honkala 1990) and efficiency in absorbing

467 and using nutrients (Reich et al. 1998; Burgess et al. 2010), jack pine was predicted to be

468 more responsive than black spruce; however, the regression analysis revealed similar

469 responses for both conifer species with respect to increasing competitive pressure exerted

470 by alder. Moreover, survival was almost $100 \%$ for both species. Wang and Kemball

471 (2010) reported a similar competitive effect on jack pine and black spruce seedlings

472 during the third growing season after planting on a recently burned site in Manitoba.

473 Competitive interactions change though time, thereby altering species-specific responses

474 to environmental modifications (Hartmann and Messier 2011). If planted alder seedlings

475 gradually dominate the site over the next few years, we expect that jack pine mortality

476 would increase drastically, but black spruce seedlings could survive long enough to 
477 eventually emerge from the alder canopy. Further monitoring is necessary to test these

478 predictions.

479

\section{Conclusions}

481 Our study demonstrates that mechanical site preparation can be used to enhance conifer

482 seedling growth over the first few years to accelerate the rehabilitation of subarctic forest

483 ecosystems. Increasing scarification treatment intensity by creating larger furrows

484 provide a significant gain in seedling dimensions compared to a standard treatment, and

485 could thus be used when intensive treatments do not create social, economic or

486 environmental issues. Our results support simultaneous planting of a nurse-plant and the

487 desired species as a promising restoration practice, especially in harsh environments such

488 as subarctic ecosystems. Planting alder after conventional disc trenching resulted in

489 growth gains for conifers that were similar to using an intensive mechanical site

490 preparation treatment, which could be useful in environmentally and socially sensitive

491 conservation areas where intensive preparation is not desirable. On the other hand, there

492 is a risk that planted mountain alder seedlings, together with the natural regeneration of

493 this species, would overgrow the planted conifers due to their rapid growth rate. Growth

494 reductions that are associated with this increased competition pressure might offset the

495 initial benefits that could be derived from planting the species. Longer-term monitoring is

496 necessary to determine whether competitive interactions between alder and planted

497 conifers would become more important than the positive effects that are incurred by the

498 species. Long-term data acquisition is also necessary to compare treatments from an

499 economic perspective, which is an issue of particular importance when conducting 
500 forestry operations in remote areas. Finally, detailed assessments of the interspecific

501 interactions are required to disentangle the mechanisms by which facilitation takes place.

502

\section{Acknowledgements}

504 We are indebted to Jacques Carignan, Maïté Brémont, Alexandre Fortin-Pelletier,

505 Evelyne Gaillard and summer students from the Direction de la recherche forestière

506 (DRF), Ministère des Forêts, de la Faune et des Parcs du Québec (MFFP), for their

507 contributions to field work and data management, to Jacques Duval (MFFP), Luc

508 Hovington (MFFP), and Denis Villeneuve (Resolute Forest Products, Montreal, QC) for

509 technical assistance, and to the staff of the Laboratoire de chimie organique et

510 inorganique of the DRF-MFFP for conducting the chemical analyses. We thank Josianne

511 DeBlois (DRF-MFFP) for statistical advice, and Maripierre Jalbert (DRF-MFFP) for her

512 help in editing Fig. 1 and Fig. 2, together with Martin-Michel Gauthier, two anonymous

513 reviewers and an Associate Editor of the journal for providing constructive advice on an

514 earlier version of the manuscript. We acknowledge the contribution of W.F.J. Parsons for

515 English revision. This study is part of DRF-MFFP project 142332106 and was partially

516 financed by the Programme de mise en valeur des ressources du milieu forestier.

\section{$518 \quad$ References}

519 Beaudoin, M., Bélanger, S., Boilard, Y., Bonneau, M., Bouchard, J., Carrière-Pagé, P.-O.,

520 Domingue, J., Dostie, R., Dupéré, P., Durand, J., Fournier, C., Gagnon, J.-C., Huot,

521 M., Innes, L., Jayen, K., Lavoie, N., Lefebvre, J.-P., Lévesque, D., Morneau, L., Piché,

522 C., Prémont, M., Rhéaume, G., and Therrien, P. 2014. Insectes, maladies et feux dans 
523 les forêts québécoises en 2013. Ministère des Forêts, de la Faune et des Parcs du

524 Québec, Direction de la protection des forêts. Québec, QC. On-line ISBN: 978-2-550-

525 70735-6(PDF)

526 Beisner, B.E., Haydon, D.T., and Cuddington, K. 2003. Alternative stable states in

527 ecology. Front. Ecol. Environ. 1(7): 376-382. doi: 10.1890/1540-9295(2003)001

$528 \quad$ [0376:ASSIE]2.0.CO;2.

529 Bellingham, P.J., Walker, L.R., and Wardle, D.A. 2001. Differential facilitation by a 530 nitrogen-fixing shrub during primary succession influences relative performance of

531 canopy tree species. J. Ecol. 89(5): 861-875. doi: 10.1046/j.0022-0477.2001.00604.x.

532 Benomar, L., DesRochers, A., and Larocque, G.R. 2013. Comparing growth and fine root 533 distribution in monocultures and mixed plantations of hybrid poplar and spruce. J. For. 534 Res. 24(2): 247-254. doi: 10.1007/s11676-013-0348-7.

535 Biging, G.S., and Dobbertin, M. 1992. A comparison of distance-dependent competition 536 measures for height and basal area growth of individual conifer trees. For. Sci. 38(3): $537 \quad 695-720$.

538 Binkley, D., Sollins, P., Bell, R., Sachs, D., and Myrold, D. 1992. Biogeochemistry of 539 adjacent conifer and alder-conifer stands. Ecology 73(6): 2022-2033. doi: 10.2307/ $540 \quad 1941452$.

541 Björklund, N., Norlander, G., and Bylund, H. 2003. Host-plant acceptance on mineral

542 soil and humus by the pine weevil Hylobius abietis (L.). Agric. For. Entomo. 5(1): 61543 66. doi: 10.1046/j.1461-9563.2003.00163.x. 
544 Blundon, D.J., and Dale, M.R.T. 1990. Dinitrogen fixation (acetylene reduction) in

545 primary succession near Mount Robson, British Columbia, Canada. Arct. Alp. Res.

$546 \quad 22(3): 255-263$. doi: $10.2307 / 1551588$.

547 Boiffin, J., and Munson, A.D. 2013. Three large fire years threaten resilience of closed

548 crown black spruce forests in eastern Canada. Ecosphere 4(5): art56 (18 pp.). doi:

$549 \quad 10.1890 /$ ES13-00038.1.

550 Bond, G. 1956. Evidence for fixation of nitrogen by root nodules of alder (Alnus) under 551 field conditions. New Phytol. 55(2): 147-153. doi: 10.1111/j.1469-8137.1956.

552 tb05276.x.

553 Brooker, R.W., Maestre, F.T., Callaway, R.M., Lortie, C.L., Cavieres, L.A., Kunstler, G.,

554 Liancourt, P., Tielbörger, K., Travis, J.M.J., Anthelme, F., Armas, C., Coll, L.,

555 Corcket, E., Delzon, S., Forey, E., Kikvidze, Z., Olofsson, J., Pugnaire, F., Quiroz,

556 C.L., Saccone, P., Schiffers, K., Seifan, M., Touzard, B., and Michalet, R. 2008.

557 Facilitation in plant communities: the past, the present, and the future. J. Ecol. 96(1):

558 18-34. doi: 10.1111/j.1365-2745.2007.01295.x.

559 Brumelis, G., and Carleton, T.J. 1988. The vegetation of postlogged black spruce

560 lowlands in central Canada. I. Trees and tall shrubs. Can. J. For. Res. 18(11): 1470-

561 1478. doi: $10.1139 / \times 88-226$.

562 Buitrago, M., Paquette, A., Thiffault, N., Bélanger, N., and Messier, C. 2015. Early

563 performance of planted hybrid larch: effects of mechanical site preparation and

564 planting depth. New For. 46(3): 319-337. doi: 10.1007/s11056-014-9463-3. 
565 Burdett, A. 1990. Physiological processes in plantation establishment and the

566 development of specifications for forest planting stock. Can. J. For. Res. 20(4): 415-

567 427. doi: 10.1139/x90-059.

568 Burgess, D., Adams, G., Needham, T., Robinson, C., and Gagnon, R. 2010. Early

569 development of planted spruce and pine after scarification, fertilization and herbicide

570 treatments in New Brunswick. For. Chron. 86(4): 444-454. doi: 10.5558/tfc86444-4.

571 Burns, R.H., and Honkala, B.H. (technical coordinators). 1990. Silvics of North America.

572 Volume 1. Conifers. Volume 2. Hardwoods. Agriculture Handbook 654. U.S.

573 Department of Agriculture, Forest Service, Washington, DC.

574 Burton, P., Messier, C., Smith, D.W., and Adamowicz, W.L. (eds). 2003. Towards

575 Sustainable Management of the Boreal Forest. NRC Research Press, Ottawa, ON.

576 Callaway, R.M., and Walker, L.R. 1997. Competition and facilitation: A synthetic

577 approach to interactions in plant communities. Ecology 78(7): 1958-1965. doi:

$578 \quad 10.1890 / 0012-9658(1997) 078[1958: C A F A S A] 2.0 . C O ; 2$.

579 Castells, E., Peñuelas, J., and Valentine, D.W. 2005. Effects of plant leachates from four

580 boreal understorey species on soil $\mathrm{N}$ mineralization, and white spruce (Picea glauca)

581 germination and seedling growth. Ann. Bot. 95(7): 1247-1252. doi:

$582 \quad 10.1093 / \mathrm{aob} / \mathrm{mci139}$.

583 Castro, J., Zamora, R., Hódar, J.A., and Gómez, J.M. 2002. Use of shrubs as nurse plants:

584 A new technique for reforestation in Mediterranean mountains. Restor. Ecol. 10(2):

585 297-305. doi: 10.1046/j.1526-100X.2002.01022.x. 
586 Chapin III, F.S., Walker, L.R., Fastie, C.L., and Sharma, L.C. 1994. Mechanisms of 587 primary succession following deglaciation at Glacier Bay, Alaska. Ecol. Monogr. 588 64(2): 149-175. doi: 10.2307/2937039.

589 Cortini, F., and Comeau, P.G. 2008. Effects of red alder and paper birch competition on 590 juvenile growth of three conifer species in southwestern British Columbia. For. Ecol. 591 Manage. 256(10): 1795-1803. doi: 10.1016/j.foreco.2008.03.022.

592 Drew, T.J., and Flewelling, J.W. 1979. Stand density management - an alternative 593 approach and its application to Douglas-fir plantations. For. Sci. 25(3): 518-532.

594 Dufour-Tremblay, G., Lévesque, E., and Boudreau, S. 2012. Dynamics at the treeline:

595 differential responses of Picea mariana and Larix laricina to climate change in eastern 596 subarctic Québec. Environ. Res. Lett. 7(4): 044038 (10 pp.). doi: 10.1088/1748-9326/ $597 \quad 7 / 4 / 044038$.

598 Fleming, R.L., Leblanc, J.-D., Hazlett, P.W., Weldon, T., Irwin, R., and Mossa, D.S. 599 2014. Effects of biomass harvest intensity and soil disturbance on jack pine stand 600 productivity: 15-year results. Can. J. For. Res. 44(12): 1566-1574. doi: 10.1139/cjfr$601 \quad 2014-0008$.

602 Frey, W. 1983. The influence of snow on growth and survival of planted trees. Arct. Alp. 603 Res. 15(2): 241-251. doi: 10.2307/1550925.

604 Greene, D.F., Macdonald, S.E., Haeussler, S., Domenicano, S., Noël, J., Jayen, K.,

605 Charron, I., Gauthier, S., Hunt, S., Gielau, E.T., Bergeron, Y., and Swift, L. 2007. The 606 reduction of organic-layer depth by wildfire in the North American boreal forest and 
607 its effect on tree recruitment by seed. Can. J. For. Res. 37(6): 1012-1023. doi:

$608 \quad 10.1139 / \mathrm{x} 06-245$.

609 Grossnickle, S.C. 2012. Why seedlings survive: influence of plant attributes. New For. 610 43(5-6): 711-738. doi: 10.1007/s11056-012-9336-6.

611 Hartmann, H., and Messier, C. 2011. Interannual variation in competitive interactions

612 from natural and anthropogenic disturbances in a temperate forest tree species:

613 Implications for ecological interpretation. For. Ecol. Manage. 261(11): 1936-1944.

614 doi: 10.1016/j.foreco.2011.02.018.

615 Hébert, F., Boucher, J.-F., Walsh, D., Tremblay, P., Côté, D., and Lord, D. 2014. Black

616 spruce growth and survival in boreal open woodlands 10 years following mechanical

617 site preparation and planting. Forestry 87(2): 277-286. doi: 10.1093/forestry/cpt052.

618 Jobidon, R., Bergeron, Y., Robitaille, A., Raulier, F., Gauthier, S., Imbeau, L., Saucier, 619 J.-P., and Boudreault, C. 2015. A biophysical approach to delineate a northern limit to 620 commercial forestry: the case of Quebec's boreal forest. Can. J. For. Res. 45(5): 515621 528. doi: $10.1139 /$ cjfr-2014-0260.

622 Johansson, K., Ring, E., and Högbom, L. 2013. Effects of pre-harvest fertilization and 623 subsequent soil scarification on the growth of planted Pinus sylvestris seedlings and 624 ground vegetation after clear-felling. Silva Fenn. 47(4): art1016 (18 pp.). doi:

$625 \quad 10.14214 /$ sf.1016. 
626 Krause, C., and Morin, H. 2005. Adventive-root development in mature black spruce and 627 balsam fir in the boreal forests of Quebec, Canada. Can. J. For. Res. 35(11): 2642628 2654. doi: $10.1139 / \mathrm{x} 05-171$.

629 Kurz, W.A., Shaw, C.H., Boisvenue, C., Stinson, G., Metsaranta, J., Leckie, D., Dyk, A., 630 Smyth, C., and Neilson, E.T. 2013. Carbon in Canada's boreal forest - A synthesis. 631 Environ. Rev. 21(4): 260-292. doi: 10.1139/er-2013-0041.

632 Littell, R.C., Milliken, G.A., Stroup, W.W., Wolfinger, R.D., and Schabenberger, O. 633 2006. SAS System for Mixed Models, 2nd ed. SAS Institute, Inc., Cary, NC.

634 Löf, M., Dey, D.C., Navarro, R.M., and Jacobs, D.F. 2012. Mechanical site preparation 635 for forest restoration. New For. 43(5-6): 825-848. doi:10.1007/s11056-012-9332-x.

636 Magee, L. 1990. $\mathrm{R}^{2}$ measures based on Wald and likelihood ratio joint significance tests. 637 Am. Stat. 44(3): 250-253. doi: 10.2307/2685352.

638 Mallik, A.U., Bloom, R.G., and Whisenant, S.G. 2010. Seedbed filter controls post-fire 639 succession. Basic Appl. Ecol. 11(2): 170-181. doi: 10.1016/j.baae.2009.11.005.

640 Margolis, H.A., and Brand, D.G. 1990. An ecophysiological basis for understanding 641 plantation establishment. Can. J. For. Res. 20(4): 375-390. doi: 10.1139/x90-056.

642 Mason, W.L., and Connolly, T. 2014. Mixtures with spruce species can be more 643 productive than monocultures: evidence from the Gisburn experiment in Britain. 644 Forestry 87(2): 209-217. doi: 10.1093/forestry/cpt042. 
645 Matthews, R.F. 1992. Alnus viridis subsp. crispa. In: The Fire Effects Information

646 System, [Online]. Fischer, W.C. (compiler). U.S. Department of Agriculture,

647 Forest Service, Intermountain Research Station, Fire Sciences Laboratory,

648 Missoula, MT. Available: http://www.fs.fed.us/database/feis/plant/shrub/alnvirc/all

649 .html [Accessed 16 June 2016]

650 McCarthy, N., Bentsen, N.S., Willoughby, I., and Balandier, P. 2011. The state of forest

651 vegetation management in Europe in the 21st century. Eur. J. For. Res. 130(1): 7-16.

652 doi: 10.1007/s10342-010-0429-5.

653 Nelson, A.S., Saunders, M.R., Wagner, R.G., and Weiskittel, A.R. 2012. Early stand

654 production of hybrid poplar and white spruce in mixed and monospecific plantations

655 in eastern Maine. New For. 43(4): 519-534. doi: 10.1007/s11056-011-9296-2.

656 Nguyen-Xuan, T., Bergeron, Y., Simard, D., Fyles, J.W., and Paré, D. 2000. The

657 importance of forest floor disturbance in the early regeneration patterns of the boreal

658 forest of western and central Quebec: a wildfire versus logging comparison. Can. J.

659 For. Res. 30(9): 1353-1364. doi: 10.1139/x00-067.

660 Nguyen, H., Herbohn, J., Firn, J., and Lamb, D. 2012. Biodiversity-productivity

661 relationships in small-scale mixed-species plantations using native species in Leyte

662 province, Philippines. For. Ecol. Manage. 274: 81-90. doi: 10.1016/j.foreco.2012.

$663 \quad 02.022$.

664 Nilsson, M.-C., and Wardle, D.A. 2005. Understory vegetation as a forest ecosystem

665 driver: evidence from the northern Swedish boreal forest. Front. Ecol. Environ. 3(8):

666 421-428. doi: 10.2307/3868658. 
667 Nilsson, U., and Örlander, G. 1999. Vegetation management on grass-dominated 668 clearcuts planted with Norway spruce in southern Sweden. Can. J. For. Res. 29(1): 669 1015-1026. doi: 10.1139/x99-071.

670 Nunez-Mir, G.C., Iannone, B.V., Curtis, K., and Fei, S. 2015. Evaluating the evolution of 671 forest restoration research in a changing world: a "big literature" review. New For. 672 46(5-6): 669-682. doi: 10.1007/s11056-015-9503-7.

673 Park, A., and Wilson, E.R. 2007. Beautiful Plantations: can intensive silviculture help 674 Canada to fulfill ecological and timber production objectives? For. Chron. 83(6): 825675 839. doi: $10.5558 / \mathrm{tfc} 83825-6$.

676 Parkinson, J.A., and Allen, S.E. 1975. A wet oxidation procedure suitable for the 677 determination of nitrogen and mineral nutrients in biological material. Comm. Soil 678 Sci. Plant Anal. 6(1): 1-11. doi: 10.1080/00103627509366539.

679 Pelletier Bergeron, S., Bradley, R.L., Munson, A.D., and Parsons, W.F.J. 2013. Physico680 chemical and functional characteristics of soil charcoal produced at five different 681 temperatures. Soil Biol. Biochem. 58: 140-146. doi: 10.1016/j.soilbio.2012.11.017.

682 Petersson, M., Örlander, G., and Nordlander, G. 2005. Soil features affecting damage to 683 conifer seedlings by the pine weevil Hylobius abietis. Forestry 78(1): 83-92. doi: $684 \quad 10.1093 /$ forestry/cpi008.

685 Piotto, D. 2008. A meta-analysis comparing tree growth in monocultures and mixed 686 plantations. For. Ecol. Manage. 255: 781-786. doi: 10.1016/j.foreco.2007.09.065. 
687 Prévost, M. 1992. Effets du scarifiage sur les propriétés du sol, la croissance des semis et 688 la compétition : revue des connaissances actuelles et perspectives de recherches au 689 Québec. Ann. Sci. For. 49(3): 277-296. doi: 10.1051/forest:19920306.

690 Reich, P.B., Walters, M.B., Tjoelker, M.G., Vanderklein, D., and Buschena, C. 1998.

691 Photosynthesis and respiration rates depend on leaf and root morphology and nitrogen

692 concentration in nine boreal tree species differing in relative growth rate. Funct. Ecol.

693 12(3): 395-405. doi: 10.1046/j.1365-2435.1998.00209.x.

694 Salonius, P.O. 1983. Effects of organic-mineral mixtures and increasing temperature on

695 the respiration of coniferous raw humus material. Can. J. For. Res. 13(1): 102-107.

696 doi: $10.1139 / \mathrm{x} 83-015$.

697 Saucier, J.-P., Baldwin, K., Krestov, P., and Jorgenson, T. 2015. Boreal Forests. pp. 7-29.

698 In Routledge Handbook of Forest Ecology. Edited by K.S.-H. Peh, R.T. Corlett and Y. 699 Bergeron. Routledge, Oxford, UK.

700 Saucier, J.P., Robitaille, A., and Grondin, P. 2009. Cadre bioclimatique du Québec. pp.

701 186-205. In Manuel de foresterie, 2nd edition. Edited by R. Doucet and M. Côté.

702 Ordre des ingénieurs forestiers du Québec, Éditions Multimondes, Québec, QC.

703 Schaalje, G.B., McBride, J.B., and Fellingham, G.W. 2001. Approximations to

704 distributions of test statistics in complex mixed linear models using SAS $®$ Proc

705 MIXED. Paper 262-26. In Twenty-Sixth Annual SAS® Users Group International

706 Conference, Long Beach, CA. Edited by SAS Institute, Inc., Cary, NC. 
707 Simard, S.W., Radosevich, S.R., Sachs, D.L., and Hagerman, S.M. 2006. Evidence for 708 competition and facilitation trade-offs: effects of Sitka alder density on pine

709 regeneration and soil productivity. Can. J. For. Res. 36(5): 1286-1298. doi: 10.1139/

$710 \quad \mathrm{x} 06-040$.

711 Soil Classification Working Group. 1998. The Canadian System of Soil Classification,

712 3rd ed. Agriculture and Agri-Food Canada. Publication 1646. NRC Research Press, 713 Ottawa, ON.

714 Spittlehouse, D.L., and Stathers, R.J. 1990. Seedling Microclimate. Land Management 715 Report 65. BC Ministry of Forests, Victoria, BC.

716 Stanturf, J.A., and Madsen, P. 2002. Restoration concepts for temperate and boreal

717 forests of North America and Western Europe. Plant Biosyst. 136(2): 143-158. doi:

$718 \quad 10.1080 / 11263500212331351049$.

719 Stanturf, J.A., Palik, B.J., and Dumroese, R.K. 2014. Contemporary forest restoration: A

720 review emphasizing function. For. Ecol. Manage. 331: 292-323. doi: 10.1016/j.

721 foreco.2014.07.029.

722 Sutherland, B.J., and Foreman, F.F. 1995. Guide to the use of mechanical site preparation

723 equipment in northwestern Ontario. Natural Resources Canada, Canadian Forest

724 Service, Great Lakes Forestry Centre, Sault Ste. Marie, ON; Ontario Ministry of

$725 \quad$ Natural Resources, Toronto, ON. 186 pp. 
726 Thiffault, N., Cyr, G., Prégent, G., Jobidon, R., and Charette, L. 2004. Régénération

727 artificielle des pessières noires à éricacées : effets du scarifiage, de la fertilisation et du

728 type de plants après 10 ans. For. Chron. 80(1): 141-149. doi: 10.5558/tfc80141-1.

729 Thiffault, N., and Jobidon, R. 2006. How to shift unproductive Kalmia angustifolia -

730 Rhododendron groenlandicum heath to productive conifer plantation. Can. J. For. Res.

731 36(10): 2364-2376. doi: 10.1139/x06-090.

732 Thiffault, N., Titus, B.D., and Moroni, M.T. 2010. Silviculture and planted species

733 interact to influence reforestation success on a Kalmia-dominated site - a 15-year

734 study. For. Chron. 86(2): 234-242. doi: 10.5558/tfc86234-2.

735 Thiffault, N., Titus, B.D., and Munson, A.D. 2005. Silvicultural options to promote

736 seedling establishment on Kalmia-Vaccinium-dominated sites. Scand. J. For. Res.

737 20(2): 110-121. doi: 10.1080/02827580510008356.

738 Titus, J.H. 2008. Nitrogen-fixers Alnus and Lupinus influence soil characteristics but not

739 colonization by later successional species in primary succession on Mount St. Helens.

740 Plant Ecol. 203(2): 289-301. doi: 10.1007/s11258-008-9549-0.

741 Ung, C.H., and Végiard, S. 1988. Problèmes d'inférence statistique reliés à la

742 transformation logarithmique en régression. Can. J. For. Res. 18(6): 733-738. doi:

$743 \quad 10.1139 / \mathrm{x} 88-112$.

744 Van Bogaert, R., Gauthier, S., Raulier, F., Saucier, J.-P., Boucher, D., Robitaille, A., and

745 Bergeron, Y. 2015. Exploring forest productivity at an early age after fire: a case study 
746 at the northern limit of commercial forests in Quebec. Can. J. For. Res. 45(5): 579-

747 593. doi: $10.1139 /$ cjfr-2014-0273.

748 Vanha-Majamaa, I., Salemaa, M., Tuominen, S., and Mikkola, K. 2000. Digitized

749 photographs in vegetation analysis: A comparison of cover estimates. Appl. Veg. Sci. $750 \quad 3(1): 89-94$.

751 Végiard, S., and Ung, C.-H. 1993. Statistical inference problems related to the

752 logarithmic transformation in regression: another method for interval estimation. Can.

753 J. For. Res. 23(5): 871-872. doi: 10.1139/x93-114.

754 Wagner, R.G., Little, K.M., Richardson, B., and McNabb, K. 2005. The role of

755 vegetation management for enhancing productivity of the world's forests. Forestry

756 79(1): 57-79. doi: 10.1093/forestry/cpi057.

757 Wagner, R.G., and Robinson, A.P. 2006. Critical period of interspecific competition for 758 four northern conifers: 10-year growth response and associated vegetation dynamics. 759 Can. J. For. Res. 36(10): 2474-2485. doi: 10.1139/X06-058.

760 Walker, L.R., Clarkson, B.D., Silvester, W.B., and Beverley, R.C. 2003. Colonization

761 dynamics and facilitative impacts of a nitrogen-fixing shrub in primary succession. J.

762 Veg. Sci. 14(2): 277-290. doi: 10.1111/j.1654-1103.2003.tb02153.x.

763 Wallertz, K., and Malmqvist, C. 2013. The effect of mechanical site preparation methods

764 on the establishment of Norway spruce (Picea abies (L.) Karst.) and Douglas fir

765 (Pseudotsuga menziesii (Mirb.) Franco) in southern Sweden. Forestry 86(1): 71-78.

766 doi: 10.1093/forestry/cps065. 
767 Walstad, J.D., and Kuch, P.J. 1987. Forest Vegetation Management for Conifer

768 Production. Wiley, New York.

769 Wang, G.G., and Kemball, K.J. 2010. Effects of fire severity on early survival and

770 growth of planted jack pine, black spruce and white spruce. For. Chron. 86(2): 193-

771 199. doi: $10.5558 / \mathrm{tfc} 86193-2$.

772 Yamasaki, S.H., Fyles, J.W., and Titus, B.D. 2002. Interactions among Kalmia

773 angustifolia, soil characteristics, and the growth and nutrition of black spruce

774 seedlings in two boreal Newfoundland plantations of contrasting fertility. Can. J. For.

775 Res. 32(12): 2215-2224. doi: 10.1139/x02-119.

776 


\section{Table list}

778 Table 1. ANOVA summary for planted jack pine and black spruce seedling foliar nutrient

779 concentrations and soil characteristics after three growing seasons

780

\begin{tabular}{|c|c|c|c|c|c|c|}
\hline & \multicolumn{6}{|c|}{ Treatment variable (fixed effects only) } \\
\hline & \multicolumn{2}{|c|}{ Treatment $(\mathrm{T})$} & \multicolumn{2}{|c|}{ Species $(\mathrm{S})$} & \multicolumn{2}{|c|}{$\mathrm{T} \times \mathrm{S}$} \\
\hline & $F$-value & $P>F$ & $F$-value & $P>F$ & $F$-value & $P>F$ \\
\hline \multicolumn{7}{|c|}{ Foliar nutrient concentrations } \\
\hline Total N & 12.91 & $<0.001$ & 11.55 & 0.002 & 0.13 & 0.944 \\
\hline $\mathrm{P}$ & 3.10 & 0.042 & 33.97 & $<0.001$ & 0.24 & 0.867 \\
\hline $\mathrm{K}$ & 3.56 & 0.051 & 59.74 & $<0.001$ & 0.78 & 0.521 \\
\hline $\mathrm{Ca}$ & 1.35 & 0.281 & 27.73 & $<0.001$ & 1.13 & 0.355 \\
\hline $\mathrm{Mg}$ & 0.84 & 0.474 & 0.15 & 0.702 & 0.77 & 0.511 \\
\hline \multicolumn{7}{|c|}{$\begin{array}{l}\text { Soil nutrient concentrations and } \\
\text { characteristics }\end{array}$} \\
\hline Total N & 0.35 & 0.793 & 12.81 & $<0.001$ & 15.88 & $<0.001$ \\
\hline $\mathrm{P}$ & 0.75 & 0.544 & 22.17 & $<0.001$ & 16.91 & $<0.001$ \\
\hline K & 3.07 & 0.058 & 17.96 & $<0.001$ & 9.62 & $<0.001$ \\
\hline $\mathrm{Ca}$ & 1.29 & 0.323 & 1.42 & 0.237 & 7.03 & $<0.001$ \\
\hline $\mathrm{Mg}$ & 2.51 & 0.108 & 8.74 & 0.004 & 11.17 & $<0.001$ \\
\hline $\mathrm{pH}$ & 2.28 & 0.132 & 0.18 & 0.671 & 10.98 & 0.005 \\
\hline CEC & 0.39 & 0.760 & 4.21 & 0.043 & 8.04 & $<0.001$ \\
\hline
\end{tabular}

Numerator degrees-of-freedom were 3, 1, and 3 for the $\mathrm{T}, \mathrm{S}$ and $\mathrm{T} \times \mathrm{S}$ effects, respectively. Denominator degrees-of-freedom (calculated using the Kenward-Roger method; Schaalje et al. 2001) for the foliar variables varied from 11.1-92, 16.8-92, and 16.3-92 for the T, $\mathrm{S}$ and $\mathrm{T} \times \mathrm{S}$ effects, respectively.

Denominator degrees-of-freedom for the soil variables varied from 12-16, 95-95.1, and 95-95.1 for the T, $\mathrm{S}$ and $\mathrm{T} \times \mathrm{S}$ effects, respectively. Analyses on foliar $\mathrm{P}$ and soil $\mathrm{P}$ were performed on square-root and $\mathrm{ln}-$ transformed data, respectively. $\mathrm{CEC}=$ cation exchange capacity. Values in bold are significant at $\alpha=0.05$. 
Table 2. ANOVA summary for planted jack pine and black spruce seedling dimensions and growth after three growing seasons

785

\begin{tabular}{|c|c|c|c|c|c|c|c|c|c|c|}
\hline \multirow{2}{*}{$\begin{array}{l}\text { Treatment } \\
\text { variable } \\
\text { (fixed } \\
\text { effects only) }\end{array}$} & \multirow{2}{*}{$\begin{array}{c}\text { Num } \\
\text { df }\end{array}$} & \multirow{2}{*}{$\begin{array}{c}\text { Den } \\
\text { df }\end{array}$} & \multicolumn{2}{|c|}{ Height } & \multicolumn{2}{|c|}{ Leader growth in 2013} & \multicolumn{2}{|c|}{ Ground-level diameter } & \multicolumn{2}{|c|}{ Volume index } \\
\hline & & & $F$-value & $P>F$ & $F$-value & $P>F$ & $F$-value & $P>F$ & $F$-value & $P>F$ \\
\hline Species (S) & 1 & 15.9 & 39.47 & $<0.001$ & 133.24 & $<0.001$ & 147.55 & $<0.001$ & 116.35 & $<0.001$ \\
\hline $\mathrm{T} \times \mathrm{S}$ & 3 & 15.9 & 1.89 & 0.172 & 7.53 & 0.002 & 3.96 & 0.028 & 3.23 & 0.051 \\
\hline
\end{tabular}

Num $\mathrm{df}=$ numerator degrees-of-freedom, Den $\mathrm{df}=$ denominator degrees-of-freedom, calculated using Kenward-Roger approximations (Schaalje et al. 2001). 


\section{$788 \quad$ Figure captions}

789 Figure 1. Schematic representation (not to scale) of one replicate block. Each block is

790 divided into four main plots, each randomly assigned to receive one of four treatments.

791 Each main plot comprises two subplots planted with either black spruce (Picea mariana)

792 or jack pine (Pinus banksiana). Circular sampling plots of $200 \mathrm{~m}^{2}$ are located in the

793 approximate centre of each subplot; all planted conifer seedlings within the circular

794 sampling plots ( $\sim 5$ per plot) are tagged for long-term growth assessments.

795

796 Figure 2. Schematic representation of angular height $(A)$, a distance-dependent

797 competition index that was calculated between target conifer seedlings and the nearest

798 Alnus viridis ssp. crispa seedling (natural or planted). For a given ratio between the

799 heights of the nearest alder seedling and a target conifer seedling, the value of $A$ increases

800 as the distance between individuals decreases.

801

802 Figure 3. Third-year seedling height (A, B), ground-level diameter (C) and leader length

803 (D) as influenced by mechanical site preparation and species. For a given panel (and

804 species in C and D), columns that are identified by the same lower-case letter do not

805 significantly differ at $\alpha=0.05$ (for ANOVA results, refer to Table 2). For treatments and

806 conifer species, data are presented as means \pm standard errors in panels $\mathrm{A}$ and $\mathrm{B}$, and as

807 back-transformed means and confidence intervals after bias correction in panels C and D.

808 In panel B, heights of alders are presented for information purposes only; box-and-

809 whisker plots include $10^{\text {th }}, 25^{\text {th }}, 50^{\text {th }}$ (horizontal bar within the box) $75^{\text {th }}$ and $90^{\text {th }}$

810 percentiles. Black closed circles denote the $5^{\text {th }}$ and $95^{\text {th }}$ percentiles. 
812 Figure 4. Relationship between third-year ground-level diameter of planted conifer

813 seedlings and their angular heights $(A)$ relative to the nearest Alnus viridis ssp. crispa

814 seedling (natural or planted). Refer to Figure 2 for a description of angular height. The

815 estimates of the slope coefficient for black spruce and jack pine were similar $(-0.011 \mathrm{~mm}$

$816^{\circ-1}$ ); the $\mathrm{Y}$-intercept was $6.2 \mathrm{~mm}$ for black spruce and $10.7 \mathrm{~mm}$ for jack pine. $R_{\mathrm{LR}}^{2}=$

817 likelihood-ratio-based $R^{2}$ (Magee 1990).

818 


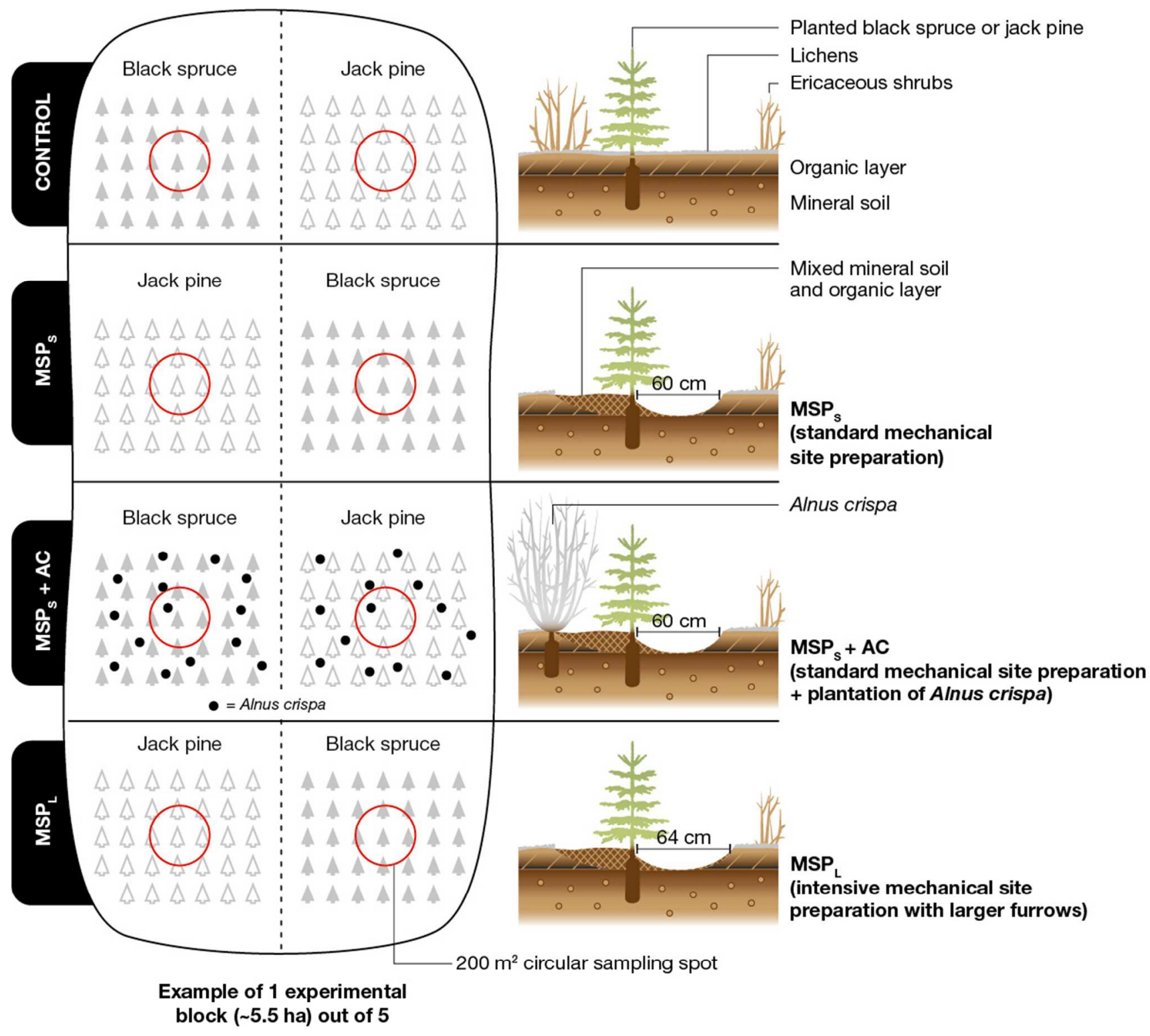

821 Figure 1. 


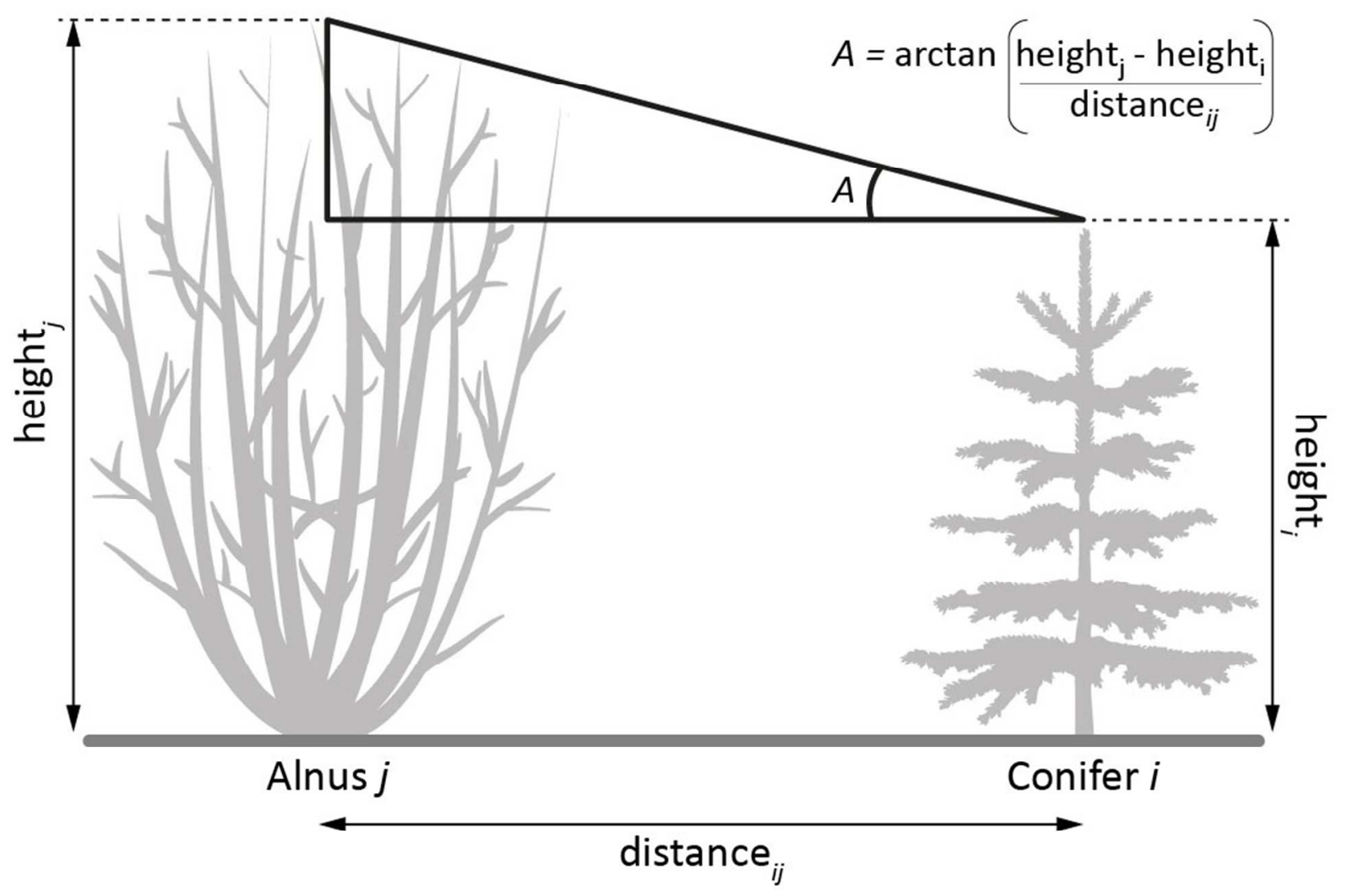

825

Figure 2.

827 

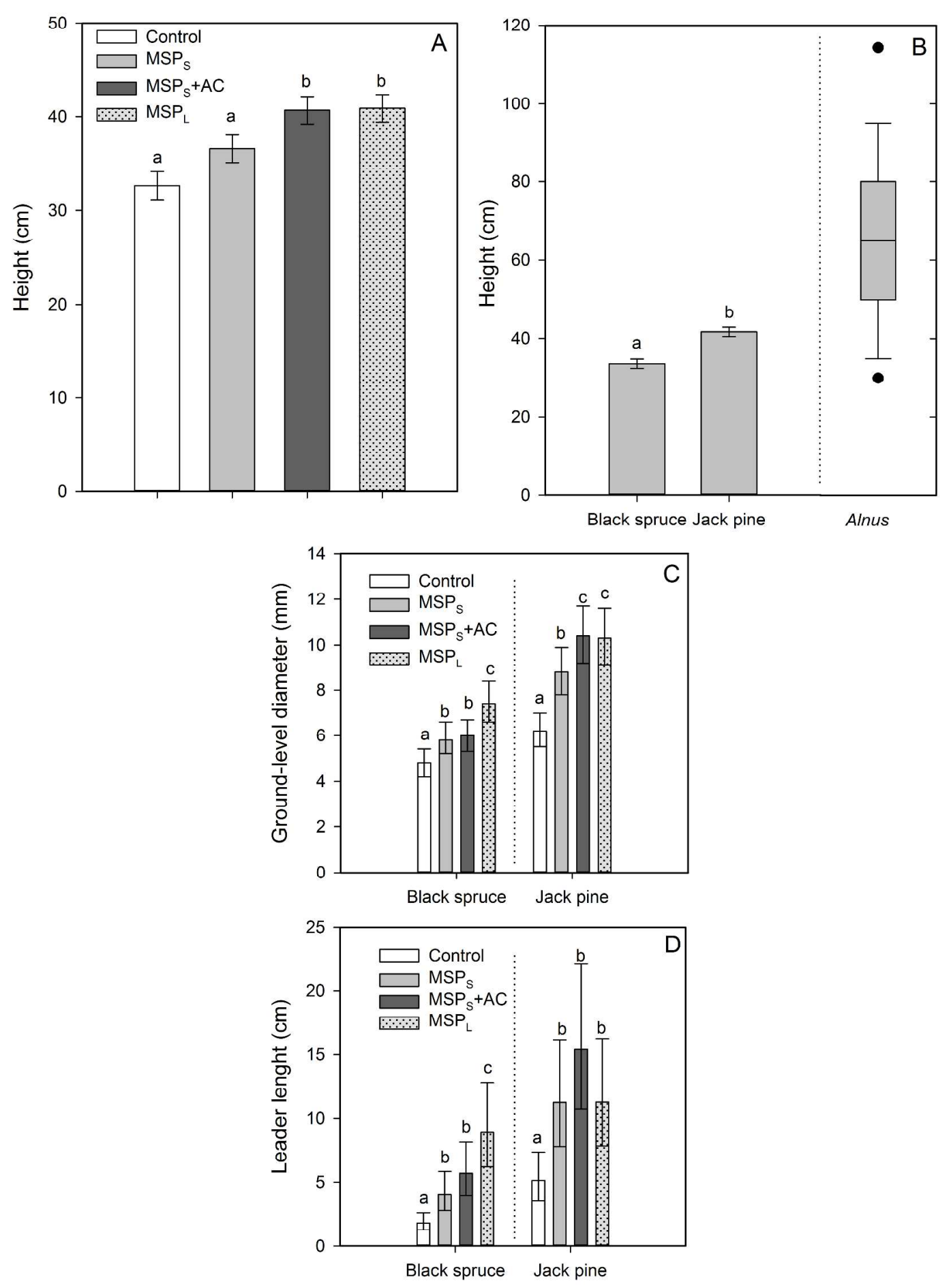

829 Figure 3. 


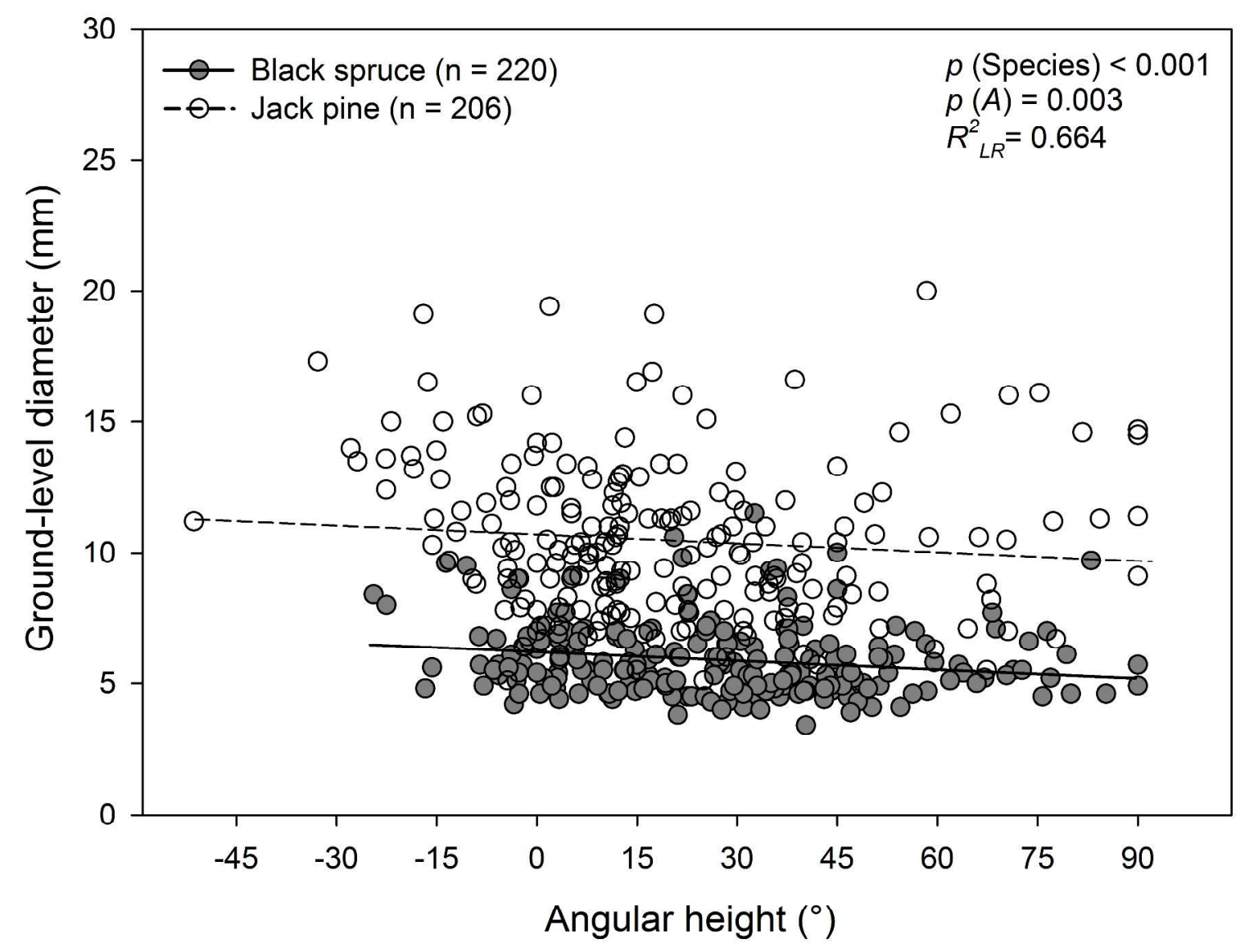

831

832 Figure 4.

833

834

835 